crepancies such as these are the necessary consequences of not having always an infecting extract of standard strength against which to test the sera, but it is difficult to get rid of a suspicion that the distinction made between the two antibodies is quantitative rather than qualitative, and that their relation to fresh serum is not that of immune body and complement as known in bacteriology. The whole narrative needs, deserves, and will doubtless receive detailed critical analysis: it is fortunate that the data are presented on such an ample scale that this is possible. The interpretation seems also in places to be inconsistent. Thus on p. 354 it is pointed out that two goats injected with heated extract (that is, containing virus only) produced sera which were active only in the presence of complement and therefore contained antiviral bodies only, and that this assumption is in accordance with general bacteriological experience. It is difficult to see how this fits with the fact (p. 361) that anti-normal-embryo sera are also active only if fresh serum is present. On p. 421 the antibody which operates in the absence of fresh serum is definitely identified with the extrinsic factor, that is, the virus. Nor is it possible to subscribe to Dr. Gye's suggestion that his immunological experiments demonstrate that extracts of fowl tumours contain some antigen which cannot have originated in the fowl and must therefore be an extrinsic virus which he thinks is widely disseminated about the world. Immunological differences between proteins depend on differences in chemical structure rather than on differences of biological origin, though in a rough way the two generally go together. Antigens from different species may be indistinguishable (blood serum of sheep and goat, egg albumin of duck and hen, various caseinogens), while antigens from the same species may be different (for example, the proteins of blood plasma or egg white) and the proteins of the lens of the eye may be antigenic in the individual to whom the eye belongs.

It seems evident that this part of Dr. Gye's argument will not carry anything like the weight that he has put on it. What his observations do seem to show quite clearly is that part at any rate of the agent is intrinsic-a conclusion in good accord with the old-fashioned view that cancer is a local autochthonous disease.

\title{
Scientific Research and National Life*
}

$\mathrm{T}^{\mathrm{H}}$ HE sixteenth Annual Report of the Department of Scientific and Industrial Research covers the period Aug. 1, 1930-July 31, 1931. It includes the brief report of the Privy Council, signed by the Right Hon. Stanley Baldwin, and the longer report of the Advisory Council, over Lord Rutherford's signature, which surveys the development of the Department and emphasises the need for scientific method in industry. Summaries of the work carried out by the National Physical Laboratory, the Chemical Research Laboratory, the research associations, and under the direction of some forty-five research boards and committees are attached, together with appendices dealing with finance, publications, and the personnel of the various boards and committees. The report presents an impressive picture of the contribution which science is making to the major needs of the population, promoting not merely material development, but also the growth of a better and healthier social order. Not only the research associations, but also the long list of committees and boards, many of whose distinguished members are rendering voluntary service which is little recognised, may be regarded as a great general staff organised for the application of science to the myriad needs of modern society.

In view of the curtailment of expenditure by the Committee of the Privy Council, particular attention is attracted to the expenditure detailed in the present report. The gross estimate for the year is

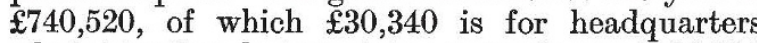
administration, but receipts amounting to $£ 184,829$ bring the net expenditure to $£ 555,691$. Grants for

* Department of Scientific and Industrial Research. Report for the Year 1930-31. (Cmd. 3989.) Pp. iv + 186. (London: H.M. Stationery Office, 1931.) 3s. net. research account for an expenditure of $£ 40,610$, gross, the Geological Survey and the Museum of Practical Geology for $£ 67,714$, and grants to research associations for $\mathfrak{£ 7 5 , 6 5 5}$. The National Physical Laboratory represents a gross expenditure of $£ 208,964$, of which slightly more than half, $£ 104,706$, is recovered as receipts from outside bodies and firms, the Air Ministry, and other government departments or special research funds. The Chemical Research Laboratory represents a charge of $£ 19,993$ net, building research, $£ 30,421$ net, fuel research, $£ 87,411$ net, radio research, $£ 12,066$ net, water pollution, $£ 10,020$ net. More than threequarters of the expenditure of $£ 50,060$ on food investigation is borne by receipts, the net cost to the State being $\mathfrak{1 1}, 693$. Receipts amounting to $£ 6936$ similarly reduce the expenditure on forest products research to $£ 36,376$.

The expenditure on research associations, of which twenty-one received grants during the year, is of special interest. The seven largest grants, of

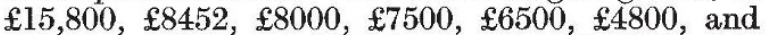
$\mathbf{\$ 4 7 5 0}$, are those paid to the Cotton, the Scientific Instruments, the Non-Ferrous Metals, the Wool Industries Research Association, the National Federation of Iron and Steel Manufacturers (Industrial Research Council), the Cast Iron Research Association, and the Research Association of the British Paint, Colour, and Varnish Manufacturers. The British Photographic Research Association was liquidated on Nov. 7, 1930, and its functions have now been taken over by the research establishments of the rationalised photographic industry. Thus

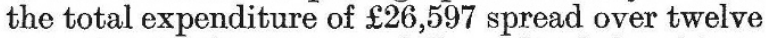
years has in this instance fully realised the objects of the Government scheme, and paved the way for

$$
\text { No. 3252, VoL. 129] }
$$


the future development of the research by the industry itself independently of financial assistance from the State. The report states: "There can be no doubt that the important scientific investigations carried out by the research association during the period of its existence have materially contributed to the marked improvement in the quality of the photographic materials and accessories produced by British firms in recent years, and the Department has received an assurance that provision will be made under the new regime for the continuance of researches of this character".

The Wool Industries Research Association anticipates that the voluntary levy scheme will be working on normal lines next year. The Research Association of the British Motor and Allied Manufacturers is also being wound up, and its place is being taken by the Research and Standardisation Committee of the Institution of Automobile Engineers, which will receive grants from the Department up to a maximum of $£ 2500$ per annum for three years on a pound for pound basis in respect of income raised by the industry above $\mathfrak{£ 3 0 0 0}$ a year. A further departure was the formation in November 1930 of the Printing Trades Research Association, which, however, is not in receipt of a grant.

Viewing the work of the research associations as a whole, the opinion is expressed that their achievements thoroughly justify the expenditure incurred, but the outstanding difficulty experienced by the research associations is that of bringing home to their members the practical significance of their work. This difficulty is being overcome, sometimes by the establishment of development departments, sometimes by the appointment of liaison officers.

Space does not permit even an outline of the work of individual research associations, and reference can only be made to a few features. The Cast Iron Research Association has developed the 'Silal' heat resisting alloys which are finding successful use in industry, and the application of the knowledge of moulding sands and refractories acquired as a result of the Association's investigations represents an estimated annual saving to the industry of about $£ 100,000$ a year. The NonFerrous Metals Research Association has been responsible for important advances in the investigation of aluminium castings and in the comparative study of a range of bearing metals and their interaction with representative lubricants. Investigations carried out by the British Refractories Research Association to improve the durability of refractory materials have an interest not only to the ceramic but also to the iron and steel and other industries concerned with high temperature operations, while much of the work carried out by the Electrical and Allied Industries Research Associa. tion is definitely related to matters of public safety and economy, for example, in the factor of safety and design of overhead transmission lines in the ' grid' system, and in the laying of electric cables at considerable depth.

The Scientific Instruments Research Association records the interesting discovery that the effect of polishing the surface of any glass, almost without exception, is to raise the refractive index of the immediate surface layer, an observation which should yield considerable information about the mechanism of polishing. The Paint Research Association has been concerned with the practical methods developed for the measurement of colour and the determination of colour fastness of pigments, and a table of fastness based on the quantitative methods developed is rapidly being accepted by the industry as the basis of colour valuation of pigments. X-ray methods are also being employed for the investigation of the structure of pigments, steels, metal deposition, and scales on steel.

The Cotton Industry Research Association has undertaken a long programme of fundamental studies on the physico-chemical nature of dye solutions and of the dyeing process, and these coordinated researches should fill a gap of much technical importance in our knowledge of the relation of the nature of dye solutions to the mechanism of cotton dyeing and the properties of the dyed material. In addition, laboratory work on the effect of various finishing processes such as bleaching and mercerising, and on the properties of cotton dyed with different dyes, is already yielding results of industrial value, and technical control of the bleaching process has been considerably improved. In a search for new uses for wool, the Wool Industries Research Association has obtained from a mixture of cellulose, leather, rubber, and wool, various products which closely resemble leather and for which uses are being explored. The Launderers' Research Association has succeeded in developing graded washing processes in which by technical control cleaner fabrics can be more rapidly obtained without increased cost of materials than by the casual processes commonly used, and methods for the economical cleansing of greasy fabrics are being evolved.

The Leather Manufacturers' Research Association has made an important contribution to public safety by the development of a method of disinfection which can be used by any tanner as a routine method of liming his goods and at the same time sterilising them against anthrax; attention is now being directed towards the development of a method by which the dry hides and skins may be disinfected at the port of entry into Great Britain. The Boot, Shoe, and Allied Trades Research Association is carrying out studies on the physical properties of leather which are intimately connected with the comfort and waterproofness of shoes. The Rubber Manufacturers' Research Association is assisting that depressed industry by discovering new uses for rubber, and particularly by studies on the use of vulcanised rubber for resisting corrosion and on the problem of securing satisfactory adhesion of rubber to metals, while the Research Association for the Cocoa, Chocolate, Sugar Confectionery, and Jam Trades has elaborated practical methods for preventing fatty bloom on chocolate and for overcoming the tendency of boiled sweets to become sticky on storage.

The above points, culled at random from the

No. 3252, VoL. 129] 
summarised accounts of the activities of the research associations, represent in themselves an impressive and important contribution to public as well as to industrial progress. They are, however, only a fraction of the work for which the Department of Scientific and Industrial Research is responsible. Reference has already been made to the National Physical Laboratory, a feature of the work of which is the assistance rendered to industry by investigations and routine tests for industrial firms. Each of the seven main divisions of the Laboratory - Physics, Electricity, Metrology, Engineering, Metallurgy, Aerodynamics, and the William Froude Laboratory-is making valuable contributions to industrial progress, sometimes directly, sometimes through work carried out for a research board or association. The erection of equipment for the production of artificial fogs has much facilitated work in progress for the Atmospheric Pollution Research Committee, while the Engineering Department has carried out for the Ministry of Transport work of such obvious practical importance as tests on concrete for roads, skidding experiments with a motor-cycle and side-car and with a small model four-wheeled vehicle. The investigations on the spinning of aeroplanes, airscrew pressure and flutter, flutter of aeroplane tails, the wind resistance of ships, as well as the influence of waves on resistance, propulsion, and pitching, are only a few of the further ways in which the work of the National Physical Laboratory reflects on the question of transport and safety which is so vital in modern society.

The work carried out under the Fuel Research Board has received a considerable amount of attention recently, particularly that concerned with the hydrogenation of coal. Equally important, however, are the physical and chemical survey of the national coal resources, the investigations on carbonisation, gas production, treatment of tar to produce satisfactory fuel oils and motor spirit, coalcleaning, and heat transfer which are proceeding quietly but steadily.

Transport, fuel, and atmospheric pollution are only three of the fields in which the work of the Department impinges broadly on daily life and needs. Important undertakings like the Southampton Docks and Water Supply, London Underground Railways, Battersea Power Station, the Millwall Drainage Tunnel, the Haweswater Reservoir Scheme, the Thames Tunnel, and the MidScottish Ship Canal have resorted to the Geological Survey for information during the year.

The Building Research Board continues its efforts to substitute a science of building for empirical methods of trial and error, and has succeeded in formulating generalisations for the laying of wood block-floors, as well as indicating causes of failures of paint coatings in buildings. Measurements of creep in the ageing of concrete have been supplemented by observations on actual structures, and other investigations endeavour to improve the efficiency of buildings from the point of view of the user. Research on steel structures has assisted in standardising practice for the design of steel-frame buildings and also in the application of electric welding to structural work in Great Britain. Certain of the investigations under the Forest Products Research Board are of interest in the same field, notably those concerned with specifications for building timber, wood preservative, and the study of dry rot and the death-watch beetle, while metallurgical research on the effect of corrosive media on boiler steel under relatively severe plastic deformation is obviously of interest in regard to public as well as industrial safety.

Similarly, the public and industrial interests of work carried out under the Water Pollution Research Board are not easily separated. The investigation on beet sugar factories' effluent had already led to modifications in the factory processes, the cost of which was at least counterbalanced by resultant economies in other directions. Laboratory work has now indicated that certain organisms are of special value in the purification of waste waters containing sugar, while the surveys of the river Tees and the Firth of Tay have indicated that polluting matter is not readily carried out to sea unless it is in the surface layer when it reaches the estuary. The scarcity of living organisms in the middle section of the Tees estuary cannot be attributed solely to pollution, and observations are being recorded on the migration of salmon and sea trout smolts. Some of the work on water pollution is linked up with investigations at the Chemical Research Laboratory, where it has been found that baseexchange materials remove from water traces of undesirable metals such as lead, copper, and zinc, which may be present in solution. Apart from its other investigations on corrosion, low-temperature tar, etc., the Chemical Research Laboratory has also been responsible for investigations on a series of fluorene derivatives containing arsenic and a new group of arsenicals analogous to trypansamide, both of which possess promising therapeutic activity.

Much valuable radio research has been carried out on the propagation of waves, aerials for transmission and reception, direction finding, and atmospherics, the significance of which is obvious to an increasingly large proportion of the population, while lubrication, illumination, and dental research, and, until April 1, 1931, the preservation and restoration of exhibits in the British Museum are among other activities of the Department the public significance of which is obvious. In regard to the latter work, which has now been transferred to the Trustees of the British Museum, mention may be made of services rendered at the Persian Art Exhibition, the use of chloramine- $T$ for removing stains produced by mould and mildew in watercolour drawings and engravings, as well as the use of vinyl acetate for strengthening porous and friable material.

No summary, however brief, of the work of the Department is complete without reference to the work of the Food Investigation Board. Some account of the investigations of this Board has recently appeared in our columns, and it is unnecessary to add more than that the work of the Food Investigation Board represents the only 
serious scientific study of the possibilities of low temperature gas-storage of fresh fruit and vegetables, and its success has already led to the erection of several commercial gas-stores for apples. Problems connected with the corrosion of cans by fruit juices and syrups have been surveyed; the transport and storage of bacon and pork as well as freezing and storage of meat and eggs are all receiving attention, while it has also been found that temperatures below $0^{\circ} \mathrm{F}$. are required for the storage of brine-frozen haddock. Other investigations at the Torrey Research Station are concerned with the design of plant for the extraction of liver oil on steam. trawlers at sea and for the smoke-curing of fish, and it is not too much to claim that the national importance of the food investigations of the Department alone justify a large proportion of the whole expenditure on scientific and industrial research. Certain it is that few fractions of the national income are more wisely administered or expended with more profit both to society and to industry than the comparatively small sums which are entrusted by Parliament to the Department of Scientific and Industrial Research.

\section{Obituary}

\section{Prof. R. Stenhouse Williams}

$\mathrm{P}$ ROF. R. STENHOUSE WILLIAMS, first director of the National Institute for Research in Dairying, who died on Feb. 2 at the age of sixty years, went to Reading in 1912 equipped for the study of the dairying industry with a thorough knowledge of bacteriology, a science for which he had the greatest reverence and the status of which he jealously guarded. His profession as a physician and his academic career assisted him in the broad outlook which he brought to bear on the industry of his adoption. As a medical man he realised the importance of the nation's milk supply ; as a bacteriologist he was scandalised by the conditions which were associated with milk production, and as a teacher he deplored the apathy and ignorance which tolerated such conditions.

With a characteristic thoroughness, Prof. Stenhouse Williams set himself to study the position, and brought his science and personal observation to bear on every stage in the passage of milk from the cow to the consumer. He did not content himself merely with working out scientific technique for the production of a clean and safe milk supply; he also realised the difficulties of the practical side and the necessity of keeping down the cost of production. It was here that his special gift of inspiring efficient social service came into full play. $\mathrm{He}$ became the friend of the farmer and of the milk distributor, inspiring in all with whom he came in contact the right mentality for their especial duties. Every grave error in the handling of milk he treated as a mistake which could be overcome by care and co-operation, and no hour of the day was too early or too late for him to give help and advice in cow byre or distributing centre.

Prof. Stenhouse Williams realised the necessity for technical education in all branches of the milk industry, and was active in the organisation of lectures, classes, and competitions with the view of increasing both the knowledge and efficiency of the workers. He was a man of very clear vision. $\mathrm{He}$ saw the foundations on which the unique nutritional value of milk is established in the order of Nature, and demonstrated on a large and convincing scale that pure and safe milk could be produced as a practical proposition. He emphasised that the work of the research institute for which he was responsible should rest on the firm foundations of fundamental science, and he stressed the necessity for a very thorough further study of the nutritional value of milk, including all possible effects produced by heat treatment. In his fight to maintain an open door for raw milk, many have crossed swords with him who could not have realised the soundness of his contention that the present necessity of harnessing the milk supply of our large towns to any processing machine is an expedient which must not exclude the recognition of a possible clean and natural milk supply under better conditions of social service.

Great and lasting as is his achievement in this work, it was the character and personality of Stenhouse Williams himself which endeared him to those who knew him well. To others, who differed from him, he presented an uncompromising front, for he was by nature a fighter.

\section{Prof. W. H. Watrkinson}

WE regret to record the death, on Feb. 14, of William Henry Watkinson, emeritus professor of engineering and director of the Walker and Harrison Hughes Engineering Laboratories of the University of Liverpool.

Prof. Watkinson, who was in his seventy-second year, was born at Keighley. His early training in the University of Glasgow brought him under the direction of Lord Kelvin, and, under the latter and Prof. Fleeming Jenkin, he aided in the manufacture, testing, and laying of trans-Atlantic cables. For a time he held a scholarship under Kelvin, and in 1888 was put in charge of the Engineering Department of the Central Science School, Sheffield. In 1893 he was appointed to the chair of engineering in the Glasgow and West of Scotland Technical College.

In 1905, Watkinson was appointed to the chair of engineering in Liverpool, and was largely responsible for the growth of that school. His efforts for engineering resulted in the building and equipment, in 1912, of the beautiful laboratories which he later directed. He was also instrumental in the foundation of the chairs of naval architecture and thermodynamics in Liverpool.

Watkinson's personal investigations related in particular to pioneer work on gas engines and air

$$
\text { No. 3252, VoL. 129] }
$$

